\title{
IMPACT OF INFORMATION COMMUNICATION TECHNOLOGY (ICT) AND MASS MEDIA USAGE ON TECHNICAL EFFICIENCY OF FISH FARMING IN OGUN STATE, NIGERIA
}

\author{
Folasade O. Oke ${ }^{1 凶}$, Gaius O. Olorunsogo ${ }^{1}$, Dare Akerele $^{1}$ \\ ${ }^{1}$ Federal University of Agriculture, Nigeria
}

\begin{abstract}
The role of information in agricultural development cannot be overemphasized, as information is vital in increasing production, improving marketing and enhancing distribution strategies. Therefore, the study examined the impact of information communication technologies on the technical efficiency of fish farming in Ogun State, Nigeria using a stochastic production frontier approach. In a cross-sectional survey, a multi-stage sampling technique was employed to elicit primary information from 120 fish farmers. Major ICT sources used by the fish farmers include television (81.7\%), radio $(79.2 \%)$ and the Internet $(68.3 \%)$. The average output of catfish has positive and significant elasticity with regards to each input variable except family labour. The inefficiency model revealed that the age of farmers, farming experience, television and radio usage were significant but negatively related. That means that any increase in any of these factors will reduce the inefficiency of fish farmers and bring about an increase in technical efficiency. This implies that it is possible to increase technical efficiency in fish farming in the study area provided that the media channel (radio and television) predominantly used is improved. This study recommends a reduction in family labour usage while at the same time encouraging young people to venture into fish farming.
\end{abstract}

Keywords: fish farming, information communication technology, stochastic frontier analysis, technical efficiency

\section{INTRODUCTION}

The fishery subsector plays a notable role in the economy of Nigeria, ranking third after crop and livestock sub-sectors, respectively, in terms of contribution to the gross domestic product (Bassey et al., 2015). The fishing industry in Nigeria is divided into three major sub-sectors: artisanal fishing, industrial fishing and aquaculture (FAO, 2015). There has been an increasing awareness of the inherent benefits of aquaculture in contributing to fish production domestically due to needs. The aquaculture sub-sector of the fishing industry contributes between $0.5 \%$ and $1 \%$ to Nigeria's domestic fish production (FAO, 2016). Ifejika et al. (2008) claimed that aquaculture production potential in Nigeria is suppressed by fish importation which explains the low exploitation of aquaculture resources that can generate over 3 million tons of fish to meet domestic demand and even ensure excess for export.

The protein deficiency in the diet is equally associated with the inability of the fish farming industry to supply the required quantity of fish (Jangampalli, 2019) Deficiency in the human diet in terms of animal protein persists even despite the contribution from the livestock and poultry industries. According to Olaoye et al. (2016), fish farming serves as an important tool for rural development as it is a source of income and it provides

\footnotetext{
$\bowtie$ Folasade O. Oke, Agricultural Media Resources and Extension Centre, Federal University of Agriculture, Nigeria, e-mail: sadekemmy@yahoo.com, https://orcid.org/0000-0001-9814-7198
} 
Oke, F. O., Olorunsogo, G. O., Akerele, D. (2021). Impact of Information Communication Technology (ICT) and mass media usage on technical efficiency of fish farming in Ogun State, Nigeria. J. Agribus. Rural Dev., 2(60), 143-150. http://dx.doi.org/10.17306/J. JARD.2021.01378

high-quality protein. Also, the benefits from fish and fishery products derived by the ever-soaring population had led to the increased demand. Thus, to bridge the gap between demand and supply of fish and fishery products, efforts must be targeted at increasing the current level of fish production by examining factors that are contributing to inefficiencies.

The need to identify the underlying factors of efficiency and to assess the effects of management measures on technical efficiency and potential output has led to a growing interest in measuring the technical efficiency of the fisheries sub-sector of the livestock industry (Kirkley et al., 1998). The target of increasing the animal protein supply in the nation could be achieved through improving the productivity and efficiency of farms. The underlying principle behind much of the studies on efficiency is that farmers are not making efficient use of the existing technology.

Sustainable economic growth and development cannot be attained in any nation, particularly the developing ones, without increased agricultural production (Abubakar et al., 2009). Purushothaman et al. (2010) concluded that for agricultural development programmes to be successful in developing countries, mass media must be incorporated as a veritable tool.

In agriculture, the role of information in enhancing agricultural development cannot be overemphasized. Information is important as it increases production potentials, improves marketing and enhances distribution strategies (Oladele and Fawole, 2007). According to Ajayi (2003) and Ani (2007), mass media used as a channel of communication can convey similar information to a vast number of people in different locations at the same time. Mass media technologies make information available to users in the form of audio-only, audio with moving pictures or prints. This technology is also used by extension service organizations, particularly in developing countries, to communicate information to farmers, on account of its perceived benefits in terms of speed (fast), wide area coverage and low cost.

According to Banmeke and Olowu (2005), mass media is an effective medium that communicates to rural farmers the latest research findings, production information and agricultural technologies, and thus contributes to increased agricultural productivity. Some of the production information communicated, according to Ani (2007) Egbule and Njoku (2010), includes application techniques of fertilizers, insecticides and fungicides, improved methods of crop cultivation, animal rearing, and soil conservation techniques, harvesting technology and storage of crops. Furthermore, Aina (1995) also documented that mass media allow the farmers to share experiences, best practices and sources of financial aids and new markets. Information on fish farming technology, construction and management, breeds and spawning, processing, storage and marketing is also communicated (Ofuoku et al., 2008). The mass media is therefore increasingly becoming a veritable tool for agriculture transformation. This study revolved around the primary factor that since the effect of electronic media have been accepted as powerful, then various extension programmes on media should be made qualitative towards activities that will promote and sustain agricultural and economic growth.

In the agricultural context of Nigeria, Ogunbameru (2001) and Alabi (2010) identified radio, television and print media as the major channels through which information can be communicated to farmers. Information from the literature reveals that the broadcasting system in Nigeria is well-developed and virile as compared to other developing countries but its potentials in communicating technological information to farmers have not fully been unleashed due to the high cost of transmission and the absence of a proper framework that can incorporate the media into the agricultural development agenda. This will go a long way in transforming the individual farmers and even the society at large from traditional to modern technique of farming.

Furthermore, the high rate of illiteracy and high cost of newspaper among the current and prospective farmers may also hinder the effective use of mass media as a medium for communicating information. Also, the editors and programme directors could be more interested in anchoring programmes that are of high commercial value by keeping away most agricultural information. Consequently, most farmers are left to rely on third parties for current agricultural information and innovations and very often there can be an element of biasedness and vested interest by the third parties concerning the disseminated information. In view of the foregoing, the study seeks to estimate the technical efficiency of fish farming because the efficiency of production is directly related to the overall productivity of the agricultural sector, given the current level of technology. The findings will provide information to guide future policy initiatives to promote and facilitate access to information in 
the study area and the country at large. Also, they will help policymakers in planning and managing information dissemination problems.

The specific objectives of the study are as follows:

- Describe socio-economic characteristics of fish farmers

- Identify various sources of information employed

- Estimate the technical efficiency of fish farmers resulting from the information they get.

\section{STOCHASTIC FRONTIER PRODUCTION FUNCTION AND TECHNICAL EFFICIENCY ESTIMATION}

Technical efficiency refers to the ability of an enterprise to produce maximum output given a set of inputs and production technology (Anang et al., 2016). Technical efficiency implies maximum output is obtained from a given level of input combination. When a smaller output is gained from the usage of some inputs in an enterprise, such an enterprise is said to be technically inefficient.

Stochastic frontier production function analyses have been widely used in econometrics and applied economics. Early application of the model includes the studies of Aigner et al. (1977) concerning the analysis of US agricultural data. The stochastic frontier model was applied to farm-level agricultural data for the first time by Battese and Corra (1977), but the technical efficiency of farms was not directly addressed in their work. The stochastic frontier production function is specified as follows:

$$
\ln Y_{\mathrm{i}}=\ln \beta_{\mathrm{o}}+\sum \beta_{\mathrm{j}} \ln X_{\mathrm{ij}}+V_{\mathrm{i}}-U_{\mathrm{i}}
$$

where:

$Y-$ is the output in a specified unit

$X$-denotes the actual input vector

$\beta_{\mathrm{j}}-$ is the vector of production function parameters.

The frontier production function $\mathrm{F}\left(X_{\mathrm{j}} \beta_{\mathrm{j}}\right)$ is a measure of maximum potential output for any particular input vector $X_{\mathrm{j}}$. The $V_{\mathrm{i}}$ and $U_{\mathrm{i}}$ cause the actual production to deviate from the frontier. The $V_{\mathrm{i}}$ captures the random variation in output which is due to factors beyond the control of the farmer (e.g. temperature, moisture, natural hazards). The $V_{\mathrm{i}}$ is assumed to be independently identically distributed with zero mean and constant variance $\left(0, \sigma_{\mathrm{v}}^{2}\right)$, and to be independent of $U_{\mathrm{i}}$. The $U_{\mathrm{i}}$ is a non-negative term representing the deviations from the frontier production, which is attributed to controllable factors (technical inefficiency). It is half normal, identically and independently distributed with zero mean and constant variance: $\mathrm{N}\left(0, \sigma_{u}^{2}\right)$. The stochastic frontier production function model is established using the maximum likelihood estimation procedure (MLE), which is a maximum technique (Olowofeso and Ajibefun, 1999).

\section{MATERIALS AND METHOD}

The study was carried out in Ijebu-Ode Local Government Area in Ogun State. It occupies a land area of about $72 \mathrm{~km}^{2}$, longitude $3.18^{\circ} \mathrm{E}$ and latitude $6.47^{\circ} \mathrm{N}$, and is the second-largest urban centre in Ogun State in terms of population and infrastructural facilities, just after Abeokuta - the state capital. A multistage sampling technique was used to select fish farmers in the study area. Stage one involved the random selection of 3 blocks from the Agricultural Development Programme (ADP) zones. Stage two involved a random selection of 2 cells from each block to receive 6 cells. In stage three, 20 fish farmers were selected from each cell, giving a total of 120 fish farmers.

Primary data were collected using a well-structured questionnaire to elicit information on output, inputs, input cost and major socio-economic characteristics. Data analysis was performed using descriptive statistics (mean, frequency counts, percentages) for objectives one and two, and a stochastic frontier production model for objective three.

\section{Model specification}

Following Zellner et al. (1966), an assumption was made that farmers maximise expected profits. Then, Cobb-Douglas stochastic frontier production model was used in a single equation below to analyse the technical efficiency of catfish farmers using the frontier program, version 4.1 (Coelli, 1994).

$$
\operatorname{Ln} Y i_{=} \beta_{0}+\Sigma_{\mathrm{i}=1}^{4} \beta_{\mathrm{i}} \ln X i+(v i-\mu i)
$$

where:

$Y$ - catfish output in kilogram $(\mathrm{kg})$ of the $i$ th fish farmer

$X_{1}$ - hired labour (man-days)

$X_{2}$ - family labour (man-days)

$X_{3}$ - quantity of feed ( $\left.\mathrm{kg}\right)$

$X_{4}$ - fish pond size (ha) 
$\mu-\mathrm{a}$ non-negative random variable associated with farmers-specific factors which contribute to farmers not achieving maximum efficiency

$v$ - a stochastic error term (including extreme weather, measurement errors; and other noise errors such as misspecification problems; poaching, industrial action)

$\beta_{\mathrm{o}}-$ constant parameter

$\beta_{\mathrm{i}}-$ coefficients to be estimated

ln - natural logarithm.

The inefficiency model $\mu_{\mathrm{i}}$ is expressed as follows:

$$
\mu_{\mathrm{i}}=\alpha_{\mathrm{o}}+\alpha_{1} Z_{1}+\alpha_{2} Z_{2}+\alpha_{3} Z_{3}+\alpha_{4} Z_{4}+\alpha_{5} Z_{5}
$$

where:

$$
\begin{aligned}
& Z_{1} \text { - farmers age (years) } \\
& Z_{2} \text { - fish farmer's household size (number of persons) } \\
& Z_{3} \text { - experience of the catfish farmers (years in fish }
\end{aligned}
$$

\section{RESULTS AND DISCUSSION}

\section{Socio-economic characteristics of catfish farmers}

The result of the descriptive statistics of the socioeconomic characteristics of catfish farmers is presented in Table 1 . The study revealed that half $(50.0 \%)$ of the respondents are 45 years old and above. This suggests that youth's involvement in fish farming is low. This may lead to a future shortfall in the supply of fish (animal protein requirement) which is one of the major dietary components important for a more productive and healthy life of the population. Those findings correspond to those made by Ifejika and Ayanda (2006);

\begin{tabular}{|c|c|c|}
\hline Characteristics & Frequency & Percentage $(\%)$ \\
\hline \multicolumn{3}{|l|}{ Age (years) } \\
\hline$<30$ & 38 & 31.7 \\
\hline $30-44$ & 22 & 18.3 \\
\hline $45-59$ & 58 & 48.3 \\
\hline$\geq 60$ & 2 & 1.7 \\
\hline \multicolumn{3}{|l|}{ Gender } \\
\hline Male & 108 & 90.0 \\
\hline Female & 12 & 10.0 \\
\hline \multicolumn{3}{|l|}{ Level of education } \\
\hline Primary education & 10 & 8.3 \\
\hline Secondary education & 26 & 21.7 \\
\hline Tertiary education & 84 & 70.0 \\
\hline \multicolumn{3}{|l|}{ Marital status } \\
\hline Single & 40 & 33.3 \\
\hline Married & 68 & 56.7 \\
\hline Widow/widower & 6 & 5.0 \\
\hline Divorced & 6 & 5.0 \\
\hline \multicolumn{3}{|l|}{ Household size } \\
\hline$<4$ & 58 & 48.3 \\
\hline $4-8$ & 48 & 40.0 \\
\hline $9-13$ & 14 & 11.7 \\
\hline \multicolumn{3}{|c|}{ Farming experience (years) } \\
\hline$<3$ & 40 & 33.3 \\
\hline $3-5$ & 52 & 43.3 \\
\hline $6-8$ & 16 & 13.3 \\
\hline$\geq 9$ & 12 & 10.0 \\
\hline
\end{tabular}
Ifejika et al. (2008) and Olayiwola (2013) who reported that the older members of the population are more involved in fish farming. In the present study, 56.7\% of fish farmers were married with a mean household size of 6 persons and most of them (90\%) were male. Information elicited from the collected data revealed that literacy level was high among the fish farmers and all of them attained a minimum of primary education. In terms of farming experience, one-third $(33.3 \%)$ had below 3 years of experience in farming, while two-thirds $(66.7 \%)$ had above 3 years of experience. Nevertheless, very few $(10.0 \%)$ had above 9 years of experience. The mean farming experience was 6 years.

Table 1. Socio-economic characteristics of catfish farmers

Source: field survey. 


\section{Sources of information among catfish farmers}

Table 2 shows the distribution of catfish farmers according to various media from which they source information to improve their efficiency. The findings from the study showed that television $(81.7 \%)$ and radio $(79.2 \%)$ were the most frequently used means of information among the farmers. This implies that the conventional medium of communication remains the most accessible medium in the study area. This result matches the findings of Arokoyo (2005); Adejo and Haruna (2009) and Aphunu and Atoma (2011) who reported that television and radio constitute the major media for extension service delivery, particularly in the rural areas, as it is cheap to set up, easy to use and it meets vital needs. Other information sources in order of usage frequency include contact groups (78.3\%), Internet (68.3\%), extension agents $(65.8 \%)$, Newspaper $(55.0 \%)$ and billboard $(25.8 \%)$.

Table 2. Distribution of catfish farmers according to sources of information

\begin{tabular}{lcccc}
\hline \multirow{2}{*}{$\begin{array}{c}\text { Information } \\
\text { source }\end{array}$} & \multicolumn{2}{c}{ Users } & \multicolumn{2}{c}{ Non-users } \\
\cline { 2 - 5 } frequency & $\begin{array}{c}\text { percent- } \\
\text { age }\end{array}$ & frequency & $\begin{array}{c}\text { percent- } \\
\text { age }\end{array}$ \\
\hline Television & 98 & 81.7 & 22 & 18.3 \\
Radio & 95 & 79.2 & 25 & 20.8 \\
Billboard & 31 & 25.8 & 89 & 74.1 \\
Newspaper & 66 & 55.0 & 54 & 45.0 \\
Contact groups & 94 & 78.3 & 26 & 21.7 \\
Extension agents & 79 & 65.8 & 41 & 34.2 \\
Internet & 82 & 68.3 & 38 & 31.7 \\
\hline
\end{tabular}

Source: field survey.

\section{The parameter estimates of the stochastic frontier production function}

The maximum likelihood estimates (MLE) of the CobbDouglas production function in Table 3 revealed that all the variables included in the model are statistically significant at $1 \%$ and positively related to the output of catfish except one that is negatively related. Both the stochastic frontier and inefficiency models were estimated simultaneously. The gamma co-efficient $(\gamma)$ is significant (1\%) which suggests the possibility of a onesided error component. This implies that technical inefficiency is very significant for the output of catfish, and therefore average production function is not a sufficient tool to represent the entire data. The gamma co-efficient $(0.84)$ suggests that $84 \%$ variation in the output of catfish in the study area is due to technical inefficiencies rather than random variability, while the remaining $16 \%$ could be attributed to other factors beyond the catfish farmers' control. This means that the cost inefficiency effects make a significant contribution to the output cost of catfish production in the study area. Furthermore, the sigma square $\left(\sigma^{2}\right)$ was positive and statistically significant at $1 \%$. This shows that sigma has a good fit and the assumption of composite error term distribution were specified correctly.

In general, a positive estimated coefficient implies that a unit increase in the magnitude of the significant variables will lead to a corresponding increase in the average output of catfish produced which is based on the margin of their respective coefficients. The co-efficient of explanatory variables in the model shows a positive and significant elasticity on the output of catfish with the corresponding quantity of input variables. Apart from the family labour cost which had a negative coefficient, all other explanatory variables included in the model had positive coefficients and were significant at $1 \%$ each, meaning that if the costs of these variables increase, the fish output will also increase. The coefficient of the cost of hired labour, feed quantity and pond size were significant and positive. This implies that a unit increase in the cost of hired labour, feed quantity and pond size will increase the output of catfish by $0.06 \%$, $421.5 \%$ and $0.94 \%$ respectively.

\section{Technical inefficiency analysis}

As shown by the inefficiency model analysis in Table 3, the signs and significance of the estimated coefficients in the inefficiency model have important implications on the farmers' technical efficiency. Age of farmers, farming experience, television and radio (information communication technology source) is significant and negatively related to technical inefficiency at different levels. At the same time, household size and the Internet as an ICT source are positively related but had no significant effect on the technical inefficiency of catfish farming in the study area. 
Oke, F. O., Olorunsogo, G. O., Akerele, D. (2021). Impact of Information Communication Technology (ICT) and mass media usage on technical efficiency of fish farming in Ogun State, Nigeria. J. Agribus. Rural Dev., 2(60), 143-150. http://dx.doi.org/10.17306/J. JARD.2021.01378

Coefficients with a negative value in the inefficiency model show that the variable will affect technical efficiency positively while coefficients with positive value will affect technical efficiency negatively.

The coefficient of the age of farmers $\left(\delta_{1}\right)$ was statistically significant at $10 \%$ and contributed negatively to inefficiency. This implies that the older the farmer, the lower the technical inefficiency or the higher the technical efficiency possibly due to experience and exposure in the farming business over time. This matches the findings by Esobhawan (2007) that age was a positive contributor to technical efficiency. However, this is contrary to the report of Akenbor and Ike (2015) who claimed that with the increase in age, farmers tend to be less productive and technical efficiency drops.

The farming experience coefficient $\left(\delta_{3}\right)$ was also significant at $1 \%$ and negatively related to technical inefficiency. This means that the lower the farming experience, the lower the inefficiency and the higher the technical efficiency in fish output in the study area. This agrees with the a priori expectation as well as the earlier report of Revilla-Molina et al. (2009) and Oyinbo et al. (2016) who claimed that fisher's experience positively impacts catfish output.

The coefficients of television $\left(\delta_{4}\right)$ and radio $\left(\delta_{5}\right)$ as information communication technology source are negative and significant at $1 \%$ each. This implies that these factors led to a decrease in technical inefficiency or an increase in technical efficiency of catfish production in the study area. The use of the Internet $\left(\delta_{6}\right)$ by farmers as a source of information was positive but not significant. This implies that the Internet as a source of agricultural information will increase inefficiency and decrease technical efficiency in catfish production in the study area. This may be due to the erratic nature of power supply and poor network coverage, because of which the use of the Internet to source information may not be efficient. Similarly, the result also showed that household size $\left(\delta_{2}\right)$ is positively related to technical inefficiency, though that relationship is not significant. The implication of this is that technical inefficiency increases as household size increases. That is, fish farmer with large household size are more likely to be technically inefficient than those with small household size. This could be due to the fact that most large households have more commitments and therefore may not participate much in the activities of the farm. This report conforms to the earlier findings of Revilla-Molina et al. (2009).
Table 3. Maximum likelihood estimate of the stochastic frontier production function

\begin{tabular}{lcrr}
\hline \multicolumn{1}{c}{ Variable } & Parameter & \multicolumn{1}{c}{ Coefficient } & \multicolumn{1}{c}{ t-ratio } \\
\hline Constant & $\beta_{0}$ & $2035.8676^{* * *}$ & 2120.2536 \\
Hired labour & $\beta_{1}$ & $0.0656^{* * *}$ & 2.5426 \\
Family labour & $\beta_{2}$ & $-401.5659^{* * *}$ & -1904.0583 \\
Feed (kg) & $\beta_{3}$ & $421.5290^{* * *}$ & 1938.9558 \\
Pond size & $\beta_{4}$ & $0.9440^{* * *}$ & 24.9077 \\
\hline Inefficiency model & & & \\
Constant & $\delta_{0}$ & $1.8978^{* *}$ & 2.0669 \\
Age of farmers & $\delta_{1}$ & $-0.0327^{*}$ & -1.6515 \\
Household size & $\delta_{2}$ & 0.0688 & 0.6170 \\
Farming experience & $\delta_{3}$ & $-0.2527^{* * *}$ & -2.5094 \\
Television & $\delta_{4}$ & $-1.1893^{* * *}$ & -2.8283 \\
Radio & $\delta_{5}$ & $-1.0264^{* * *}$ & -3.0109 \\
Internet & $\delta_{6}$ & 0.5289 & 1.1874 \\
Sigma-squared & $\sigma^{2}$ & $0.2546^{* * *}$ & 3.9906 \\
Gamma & $\Gamma$ & $0.8379^{* * *}$ & 19.5771 \\
Likelihood ratio test & $\Lambda$ & -4.05084 & \\
\hline
\end{tabular}

*** and * denote statistical significance of $1 \%$ and $10 \%$, respectively.

Source: field survey.

\section{CONCLUSION AND RECOMMENDATIONS}

The study examined the effects of information communication technology and mass media usage on catfish farming technical efficiency using single-stage modelling of stochastic frontier approach. The findings from the study revealed that fish farmers' access to information communication technology in the study area is still mostly conventional as most of the farmers sought information from television and radio to meet their needs. Catfish farming is profitable in the study area and a unit increase in the cost of hired labour, feed quantity and pond size will increase the output of catfish by $0.06 \%$, $421.5 \%$ and $0.94 \%$, respectively.

The inefficiency model results reveal that age, farming experience, television and radio, as the means of information communication technology, are negatively related. That implies that the increase in those factors 
Oke, F. O., Olorunsogo, G. O., Akerele, D. (2021). Impact of Information Communication Technology (ICT) and mass media usage on technical efficiency of fish farming in Ogun State, Nigeria. J. Agribus. Rural Dev., 2(60), 143-150. http://dx.doi.org/10.17306/J. JARD.2021.01378

reduces inefficiency among the fish farmers in the study area.

The policy implication given the above findings is that the government at all levels should assist catfish farmers to solve the challenge of the high cost of feeds through subsidy and possibly through the use of local materials to reduce the cost of production and further increase output. Media channels (television and radio) being used by the farmers to source information should be improved to increase farmers' efficiency. Also, farmers should improve their search for information on better methods and technologies in fish farming. Excessive family labour usage should be reduced to increase efficiency. Also, further studies are required concerning feed management in a commercial catfish production system where efficiencies can be measured and compared among local and foreign feed users across states and agro-ecological zones. This will help solve problems arising from feeding in catfish production.

\section{SOURCE OF FINANCING}

The research was financed by the authors.

\section{REFERENCES}

Abubakar, B.Z., Ango, A.K., Buhari, U. (2009). The Roles of Mass Media in Disseminating Information to Farmers in Birnin Kebbi Local Government Area of Kebbi State: A case study of state Fadama 11 Development Project. J. Agric. Ext., 13(2), 42-54.

Adejo, P.E., Haruna, U. (2009). Access of farmers to ICTs for agricultural development in Bauchi Local Government Area, Bauchi State. In proceedings of the $43^{\text {rd }}$ annual conference of the Agricultural Society of Nigeria held in Abuja, 2009 (pp. 704-707).

Aigner, D.J., Lovell C.A.K., Schmidt, P. (1977). Formulation and estimation of stochastic frontier production function model. J. Econ., 6, 21-37.

Aina, L.O. (1995). Information and Agriculture in Africa. In: L.O. Aina, A.M. Kaniki, J.B. Ojiambo (Eds.), Agricultural Information in Africa. World Information Services Ltd, Ibadan (pp. 67-69).

Ajayi, M.T. (2003). Analysis of Mass Media Use for Agricultural Information by farmers in Egbeda Local government of Oyo State. Nigeria. J. Ext. Sys., 19(2), 45-55.

Akenbor, A.S., Ike, P.C. (2015). Analysis of technical Efficiency of Catfish Farming in Edo State, Nigeria. JBAH, 5(2), 96-101.
Alabi, E.J. (2010). Farmers' Perception of Mass Media as Channels of Extension Service Delivery; A Case study of Yola North and south Local Government Areas of Adamawa State. Unpublished B. Tech Project, Federal University of Technology Yola.

Anang, B.T., Stefan B., Timo, S. (2016). Agricultural microcredit and technical efficiency: The case of smallholder rice farmers in Northern Ghana. J. Agric. Rural Dev., 117, 189-202.

Ani, A.O. (2007). Agricultural Extension: A Pathway for Sustainable Agricultural Development (pp. 15-28). Kaduna: Apani Publishers.

Aphunu, A., Atoma, C.N. (2011). Extent of Use of ICTs by Fish Farmers in Isoko Agricultural Zone of Delta State, Nigeria. J. Agric. Ext., 15(1), 10-21.

Arokoyo, T. (2005). ICTs application in agricultural extension services delivery in Nigeria. In: S.F. Adedoyin (Ed.), Agricultural Extension in Nigeria (pp. 245-251). Agricultural Extension Society of Nigeria, Ilorin, Nigeria.

Banmeke, T.O., Olowu, T.A. (2005). Accessibility of Women Farmers to Agricultural Information in South Western Nigeria. S. Afr. J. Agric. Ext., (34)2, 237-243.

Bassey, N.E., Uwemedimo, E.O., Uwem, U.I., Edet, N.E. (2015). Analysis of the determinants of fresh fish marketing and profitability among captured fish traders in SouthSouth, Nigeria: the case of Akwa-Ibom State. BJEMT, 5(1), 35-45.

Battese, G.E., Corra, G.S. (1977). Estimation of a production frontier model with application to the pastoral zone of Eastern Australia. Aust. J. Agric. Eco, 22, 169-179.

Coelli, T.J. (1994). A Guide to Frontier Version 4.1: A computer program for stochastic, frontier production and cost function estimation. Armidale: Mimeo, Department of Econometrics, University of New England.

Egbule, P.E., Njoku, E.M. (2010). Mass Media Support for Adult Education in Agriculture in Sourthern Nigeria. Retrieved from: http://.iizdvv.de/index.php?article $\mathrm{id}=4838$ \&clang $=26 / 7 / 2011$

Esobhawan, A.O. (2007). Efficiency Analysis of Artisanal Fishery Production in Edo State, Nigeria. PhD Thesis. Ekpoma: Ambrose Alli University.

FAO (Food and Agricultural Organization) (2015). Guide to fisheries sector studies.www.fao.org http://www.fao. org/3/V4715E/V4715E12.htm

FAO (Food and Agricultural Organization) (2016). The State of World Fisheries and Aquaculture: Contributing to Food Security and Nutrition for All. Rome: FAO.

Ifejika, P.I., Ayanda, J.O. (2006). Status of aquaculture in Kainji Lake Basin of Nigeria. In: E.J. Ansa, P.E. Anyanwu, S.N. Deekae (Eds). Fish for food and income generation in Nigeria. Proceedings of the 20th Annual Conference of 
Oke, F. O., Olorunsogo, G. O., Akerele, D. (2021). Impact of Information Communication Technology (ICT) and mass media usage on technical efficiency of fish farming in Ogun State, Nigeria. J. Agribus. Rural Dev., 2(60), 143-150. http://dx.doi.org/10.17306/J. JARD.2021.01378

Fisheries Society of Nigeria (FISON), Port Harcourt, 1418 November, 2005 (pp. 281-286).

Ifejika, P.I., Akinbile, L.A., Ifejika, L.I., Oladeji, J.O. (2008). The socio-economic effects on adoption of aquaculture technologies among fish farmers in Anambra State, Nigeria. J. Agric. Ext., 11, 74-86.

Jangampalli, A.D. (2019). Aquaculture role in global food security with nutritional value: a review. Trans. Anim. Sci., 3(2), 903-910; https://doi.org/10.1093/tas/txz012

Kirkley, S.E., Savery, J.R., Grabner-Hagen, M.M. (1998) Electronic Teaching: Extanding Classroom Dialogue and Assistance Through E -mail Communication. In: C.J. Bonk, K.S. King (Eds). Electronic Collaborators: Learner-Centered Technologies for Literacy, Apprenticeship, and Discourse. London: Lawrence Erlbaum Associates Publishers.

Ofuoku, A.N., Emah, G.N., Itedjere, B.E. (2008). Information utilization among rural fish farmers in Central Agricultural Zone of Delta State Nigeria. World J. Agric. Sci., 4(5), 558-564.

Ogunbameru, B.O. (2001). Practical Agricultural Communication. Ibadan: Daily Graphics.

Oladele, O.L., Fawole, O.P. (2007). Multillinquality of farm broadcast and agricultural information access in Nigeria. J. Hum. Eco., 21(3), 191-194.

Olaoye, O.J., Ojebiyi, W.G., Opele, A.I., Baiyewu, A.K. (2016). Socioeconomic analysis of small scale fish farmers in Ilaro agricultural extension zone of Ogun State, Nigeria. J. Agric. Forest. Fish., 15(2), 64-74.

Olayiwola, O.O. (2013). Technical Efficiency of Fish Production in Ijebu-Ode of Nigeria. J. Res. Mgt. Tech., 2(1), 26-42.

Olowofeso, O.E., Ajibefun, I.A. (1999). The Maximum Likelihood Estimation of Stochastic Frontier Production Function with Technical Efficiency Using Time Series Data. J. Sci. Eng. Tec., 6, 1527-1536.

Oyinbo, O., Mohammed, O.M., Falola, A., Saleh, M.K. (2016). Technical Efficiency of Catfish Farming in Alimosho Local Government Area of Lagos State, Nigeria: A Gender Perspective. Agric. Trop. Subtrop., 49, 45-49.

Purushothaman, C., Kavaskar, M., Reddy, Y.A., Kanagasabapathi, K. (2010). Role of Mass Media in Agriculture. Retrieved from: http://docs.google.com/ viewer? $\mathrm{a}=\mathrm{v} \& \mathrm{q}=$ cache!nXmlzKKU5_8j

Revilla-Molina, I.M., Bastiaans, L., van Keulen, H., Mew, T.W., Zhu, Y.Y., Villano, R.A. (2009). Improvement of technical efficiency in rice farming through interplanting: A stochastic frontier analysis in Yunnan, China. DEGIT Conference Papers,c013_c015. https://ideas.repec.org/s/ deg/conpap.html

Zellner, A., Kmenta, J., Drez, J. (1966). Specification and estimation of Cobb-Douglas production function models. Econometrica, 34, 785-795. 